\title{
SOME CLINICAL, BIOCHEMICAL AND GENETIC OBSERVATIONS ON HEMOGLOBIN C
}

\author{
By HELEN M. RANNEY, DANIEL L. LARSON, ${ }^{1}$ AND GEORGE H. MCCORMACK, JR. \\ (From the Department of Medicine, College of Physicians and Surgeons, Columbia University, \\ and the Presbyterian Hospital in the City of New York, N. Y.)
}

(Submitted for publication July 1, 1953; accepted August 3, 1953)

Recent observations $(1,2)$ in certain American Negroes, of a previously unrecognized abnormal hemoglobin, now designated as hemoglobin $\mathrm{C}^{2}{ }^{2}$ constitute a significant advance in knowledge of familial anemias. The introduction of filter paper electrophoresis $(3,4)$ for identification of abnormal hemoglobins $(5,6)$ has facilitated the study of specimens of hemoglobin from a large number of subjects. With this laboratory procedure, the presence of hemoglobin $\mathrm{C}$ alone or in combination with another hemoglobin can readily be detected.

This report deals with the clinical and hematological manifestations which have been encountered in patients with hemoglobin $C$. Of the total of twelve individuals included in the present study, one patient was found to have hemoglobin $\mathrm{C}$ alone, and thus represented the homozygous state for the gene for this abnormal hemoglobin. Five patients had the combination of genes for sickle and $C$ hemoglobin and therefore belong to the group of patients with "sickle cell-hemoglobin C disease" (7) first described by Kaplan, Zuelzer, and Neel (1). The findings in six individuals with a mixture of hemoglobin $\mathrm{C}$ and normal hemoglobin are summarized in the discussion. The finding of a patient whose hemoglobin was entirely of the " $\mathrm{C}$ " variety afforded an opportunity to study some of the physico-chemical characteristics of this abnormal hemoglobin, which are included in the present report.

\footnotetext{
1 Present address: Army Medical Service Graduate School, Washington, D. C.

2 The designation of hemoglobins in this report conforms with the recommendations of the Symposium of the Hematology Study Section of the Division of Research Grants of the National Institutes of Health (Blood, 1953, 8, 386).
}

\section{CASE HISTORIES}

Homozygosity for the gene for hemoglobin $C$ : "Hemoglobin C Disease"

M. B., a Negro housewife, 35 years of age, had two brief episodes of joint pains at age 21 and at age 24 . Each episode consisted of two to three days of swelling and of tenderness of wrist and interphalangeal joints with prompt and complete clearing of symptoms thereafter. She had four uneventful pregnancies and four living children. The patient was first seen here in 1946 at the age of 29, for arthralgias and urticaria of one week's duration. Physical examination revealed a small, well developed, well nourished young Negro woman who appeared neither acutely nor chronically ill. No unusual features of skeletal development were noted. The spleen was palpable $5 \mathrm{~cm}$. below left costal margin, urticarial lesions were scattered over the face, trunk and extremities, and the right ankle joint was noted to be slightly swollen and tender.

Laboratory studies showed a hemoglobin of $10 \mathrm{Gm}$. per $100 \mathrm{ml}$., hematocrit of 31 per cent, red blood cell count of 3.2 million per cu. mm., leucocyte count of 10,400 per cu. $\mathrm{mm}$., with a normal differential count. The stained bloodsmear showed nearly 100 per cent target cells with anisocytosis, poikilocytosis and polychromatophilia. Reticulocytes numbered 3.3 per cent, with platelets of 212,000 per cu. mm. Sickling preparation was negative. An osmotic fragility test showed decreased fragility to hypotonic saline (range 0.375 per cent to 0.20 per cent for patient's erythrocytes; control 0.45 per cent to 0.30 per cent). The sedimentation rate was $6 \mathrm{~mm}$. in one hour (Westergren). The serum bilirubin was $1.2 \mathrm{mg}$. per cent. Urinalysis was negative and cephalin flocculation test was negative. The serum albumin was $4.8 \mathrm{Gm}$. per cent and serum globulin was $2.2 \mathrm{Gm}$. per cent. X-rays of the chest revealed normal heart size. No bony abnormalities were noted in $\mathbf{x}$-rays of the skull or chest.

Urticaria and joint pains subsided within a few days and have not recurred. The patient has been seen frequently during the last six years and has been completely asymptomatic. The splenomegaly has not changed during that time. She received $1.2 \mathrm{Gm}$. of ferrous sulfate daily for five years; however, the hemoglobin level has remained between 10 and $12 \mathrm{Gm}$. per $100 \mathrm{ml}$. with reticulocytes of 3 or 4 per cent. Many target cells have been present on all stained blood smears. Bone marrow aspiration showed erythroid hyperplasia. Coombs' test was negative, repeated sickling tests, employing either 
Incidence of various hemoglobins in
Fomily $B$

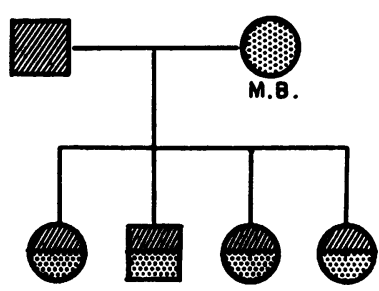

mumums normal he moglobin

hemoglobin $C$

Fig. 1. Patient (M. B.) Homozygous for the Gene FOR HEMOGLOBIN C

sealed wet preparations or sodium metabisulfite, have been negative and erythrocytes have continued to show decreased osmotic fragility. Mechanical fragility (8) was slightly increased, as shown by values of 9 per cent and 11 per cent (normal less than 6 per cent by method used in this laboratory). In 1952, filter paper electrophoresis showed that all of the hemoglobin of this patient was of the hemoglobin $\mathrm{C}$ variety.

The incidence of hemoglobin $\mathrm{C}$ in the family of this patient is depicted in Figure 1.

The combination of genes for sickle cell hemoglobin and hemoglobin C: "Sickle cell-hemoglobin C disease"

\section{Case I}

M. S., a 15-year-old Puerto Rican boy, was first seen in 1952 because of pain in the right knee of 12 hours' duration. The family history revealed that he had one younger sister who had attacks of joint pains accompanied by jaundice. His maternal great-grandmother was said to have been Negro. Since the age of five years, the patient had had attacks of migratory polyarthritis which were transient and cleared without residual joint deformity. With several of these episodes of arthritis, he was thought to have been icteric.

Physical examination revealed a short, well developed Puerto Rican boy with pain in the right knee. There was no jaundice or cardiac murmur. The liver and spleen were not palpable. The right knee showed slight swelling with tenderness, increased heat and limitation of motion. No other joints were involved.

Laboratory study revealed a hemoglobin of $12 \mathrm{Gm}$. per $100 \mathrm{ml}$., erythrocytes of 3.8 million per $\mathrm{cu} . \mathrm{mm}$., white blood cells of 5700 per cu. mm. with a normal differential count. Many target cells were noted in the stained smear. Sickle cell preparation was positive. Reticulocytes were 2.9 per cent. Serum bilirubin was $0.9 \mathrm{mg}$. per cent. An electrocardiogram was within normal limits and the chest $\mathbf{x}$-ray showed questionable cardiac enlargement. Roentgenograms of the skull, chest and knees showed no bony abnormalities. The pain in the right knee subsided within a few days and the patient was asymptomatic thereafter. The filter paper electrophoretic pattern of the hemoglobin of this patient revealed a mixture of sickle cell and C hemoglobin. Subsequently blood specimens of other members of the family were received from Puerto Rico; the distribution of various hemoglobins in members of this family is shown in Figure 2. The sister, who also had recurrent bouts of arthritis and jaundice, had a hemoglobin pattern identical with that of the patient. The patient's family lived in Puerto Rico and was unavailable for other studies.

\section{Case II}

C. S., a 22-year-old Negro male, was first seen in 1951 when he had a brief episode of pain in the low back and in the left testicle. Five years before, an episode of arthritis of the hips and knees, followed by painless hematuria, had been called acute rheumatic fever. Physical examination in 1951 was normal except for a spleen palpable $5 \mathrm{~cm}$. below the left costal margin. Laboratory studies revealed a hemoglobin of $10.4 \mathrm{Gm}$. per $100 \mathrm{ml}$., erythrocyte count of 3.9 million per cu. mm., leucocytes of 6900 per cu. mm., with a normal differential count. Many target cells were noted on the stained smear. Sickling preparation was positive and ESR was $11 \mathrm{~mm}$. in one hour (Westergren).

In 1951, painless hematuria recurred. Retrograde pyelograms showed changes suggestive of pyelonephritis. Urine specimens were negative for tubercle bacilli. An electrocardiogram was within normal limits; chest $x$-ray showed slight cardiac enlargement. Except for hematuria, the patient has remained asymptomatic. Filter paper electrophoresis of his hemoglobin in 1952 showed a mixture of sickle and $\mathrm{C}$ hemoglobin. Results of further hemoglobin studies carried out on members of this family are depicted in Figure 3.

\section{Case III}

C. W., a Negro woman, was first seen in 1948 at the age of 24 during her first pregnancy. She had had re-

\section{Incldence of various hemoglobins in Family M.S.}

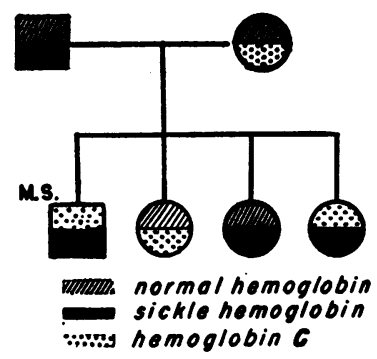

Fig. 2. Patient (M. S.) Has Combination of Genes for Hemoglobin C and Sickle Cell Hemogrobin 
current bouts of arthralgias, sometimes accompanied by swelling of the joints, during the past 11 years. No abnormalities were noted on physical examination during the third month of pregnancy. Pregnancy proceeded uneventfully until the eighth month when the patient developed pleuritic pain and fever with changes in the chest $\mathbf{x}$-ray compatible with pneumonia or with pulmonary infarctions. With this illness the hemoglobin fell to 4.8 $\mathrm{Gm}$. per $100 \mathrm{ml}$. (from a level of $9.5 \mathrm{Gm}$. per $100 \mathrm{ml}$. during the third month of pregnancy), and the white blood cell count was found to be 3070 per cu. mm. There were 11 per cent myelocytes and 95 nucleated erythrocytes per 100 leucocytes on the stained blood smear. No increase in reticulocytes occurred; osmotic fragility was decreased ( 0.32 per cent to $<0.28$ per cent saline for erythrocytes of patient; control 0.40 per cent to 0.32 per cent saline). Premature labor began on the third day of hospitalization, and a living male infant was delivered. The pulmonary lesions and fever slowly subsided, and the anemia responded satisfactorily to blood transfusions. When the patient was seen one month later, splenomegaly was noted, the hemoglobin had risen to $12 \mathrm{Gm}$. per $100 \mathrm{ml}$. and sickling was demonstrated for the first time. Since then, blood smears have repeatedly shown numerous target cells with anisocytosis and polychromatophilia. The patient has been well except for aching pains in the left leg. X-rays of the left hip have shown progressive sclerosis and flattening of the left femoral head, probably the result of ischemic necrosis. Filter paper electrophoretic analysis of her hemoglobin, done in 1952, revealed the combination of sickle cell hemoglobin and hemoglobin C.

\section{Case IV}

M. D., a Negro girl was first seen in the Babies' Hospital in 1951 at the age of 12 for low-back pain of six hours' duration. There was no history of any previous bone or joint pain and six hours after its onset the back pain had disappeared. Physical examination was entirely negative except for a palpable spleen tip. Laboratory studies showed hemoglobin to be $6.0 \mathrm{Gm}$. per $100 \mathrm{ml}$., leucocytes numbered 10,900 per cu. mm. with 84 per cent polymorphonuclear leucocytes. Reticulocytes were 3.9 per cent and a sickling preparation was positive. She had a low-grade fever during the early part of hospitalization and there was a transient increase in the splenomegaly. Since hospitalization she has been completely asymptomatic and the hemoglobin level has ranged from 8 to 11 $\mathrm{Gm}$. per $100 \mathrm{ml}$. Her hemoglobin was studied in 1952 and found to be a mixture of sickle hemoglobin and hemoglobin C.

\section{Case $V$}

E. H., a Negro boy, was first admitted in 1952 at the age of 12, for weight loss of two and one-half months' duration. The patient had had an episode of painless hematuria two and one-half months before admission and although the hematuria disappeared, weight loss had con-
Incidence of various hemoglobins in Fomily C.S.

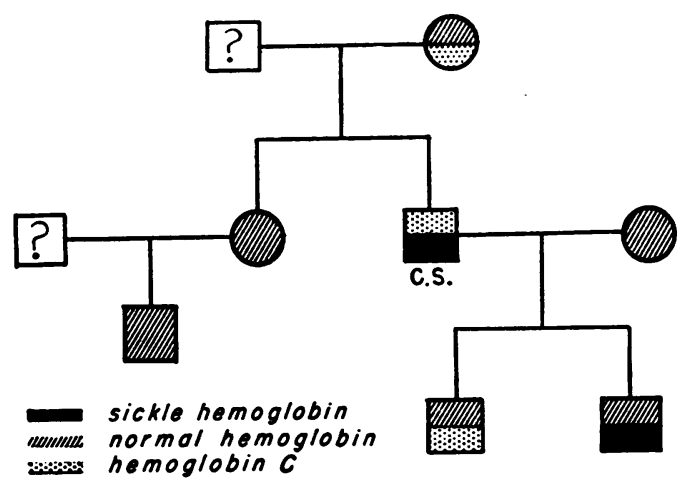

Fig. 3. Patient (C. S.) Has Combination of Genes for Hemoglobin C and Sickle Cell Hemoglobin

tinued since that time. There was no previous history of anemia, of bone or joint pain or of jaundice.

Physical examination revealed an alert well developed boy not appearing ill. The liver was slightly enlarged and the spleen was felt $4 \mathrm{~cm}$. below left costal margin. Laboratory studies revealed a hemoglobin of $10.5 \mathrm{Gm}$. per $100 \mathrm{ml}$. with white blood cells 4600 per cu. mm. and a normal differential count. Numerous target cells were seen on the blood smear. Two sickling preparations were negative. Increased resistance to hypotonic saline was noted in the osmotic fragility test (range from 0.425 per cent to 0.225 per cent saline for patient's erythrocytes with control range from 0.500 per cent to 0.375 per cent saline).

$\mathrm{X}$-rays of the chest showed tuberculosis of the childhood type in the right lung, and gastric aspiration was positive for acid-fast bacilli. Urological studies, including retrograde pyelography and examinations of specimens of urine for tubercle bacilli yielded no evidence of genito-urinary tuberculosis.

Further studies, including G.I. series, barium enema and intravenous urography, were all within normal limits. Because there was some uncertainty about the nature of the left upper quadrant mass, an exploratory celiotomy was done. The mass was identified as an enlarged spleen, and a splenectomy was performed. The histological examination of the spleen suggested sickle cell anemia and subsequently, several sickling preparations were positive. The patient recovered uneventfully from the operation. However, since discharge from the hospital, chest $x$-rays have shown progression of the pulmonary tuberculosis.

The slight anemia was apparently not affected by splenectomy; one year after the operation the hemoglobin was $10.6 \mathrm{Gm}$. per $100 \mathrm{ml}$. with leucocytes of 7000 per cu. mm., and reticulocytes of 2.4 per cent. Filter paper electrophoresis, carried out in 1953, revealed this patient's hemoglobin to be a mixture of sickle hemoglobin and hemoglobin $\mathrm{C}$. 


\section{GENETIC STUDIES}

The results of hemoglobin studies in members of three families in which hemoglobin $\mathrm{C}$ occurred, are shown in Figures 1 to 3 . In family M. S., three types of offspring resulted from the mating of a male with sickling trait and a female with hemoglobin $\mathrm{C}$ trait. Two of the children had the doubly abnormal heterozygous state for genes responsible for hemoglobin since their hemoglobin was a mixture of sickle and $\mathrm{C}$ hemoglobin; a third child had hemoglobin $C$ trait and a fourth had sickling trait. The fourth possible combination, i.e., of entirely normal hemoglobin, occurred in none of the offspring.

Patient M. B. (homozygous for the gene for hemoglobin $($ ), her husband, whose hemoglobin was normal, and their four children provided an unusual opportunity to study the mode of inheritance of hemoglobin C. Each of the four children was found to have the combination of hemoglobin $\mathrm{C}$ and normal hemoglobin. That all of these children, genetically first generation $\left(F_{1}\right)$ hybrids, are uniform in their hereditary traits with respect to hemoglobin, is strong evidence that the presence of hemoglobin $C$ is determined by a gene which is transmitted as a simple, although incomplete, Mendelian dominant.
This hypothesis first formulated by Kaplan, Zuelzer, and Neel (1), received further support from the studies in family C. S. In this family, where C. S., the father, had two abnormal hemoglobins (sickle cell and $C$ hemoglobin), and the mother had normal hemoglobin, one son had a mixture of sickle and normal hemoglobin, and the other son, a mixture of hemoglobin $\mathrm{C}$ and normal hemoglobin.

\section{Studies of hemoglobin C}

The studies of hemoglobin $\mathrm{C}$ employed hemoglobin specimens prepared by the method of Drabkin (9) from the blood of patient M. B.

Filter paper electrophoresis was carried out on samples of hemoglobin $\mathrm{C}$, normal hemoglobin and sickle hemoglobin; dye elution curves, prepared by the method previously described (6), are shown in Figure 4. Under the conditions employed for filter paper electrophoresis, hemoglobin $\mathrm{C}$ has the lowest mobility of any hemoglobin studied. The great difference in mobility of hemoglobin $\mathrm{C}$ and the other hemoglobins makes filter paper electrophoresis a suitable technique for the identification of this abnormal hemoglobin.

Moving boundary electrophoresis was carried out on specimens of hemoglobin C. Veronal

\section{ELUTION GUAVES OF MUMAM MEMOCLOBIN}

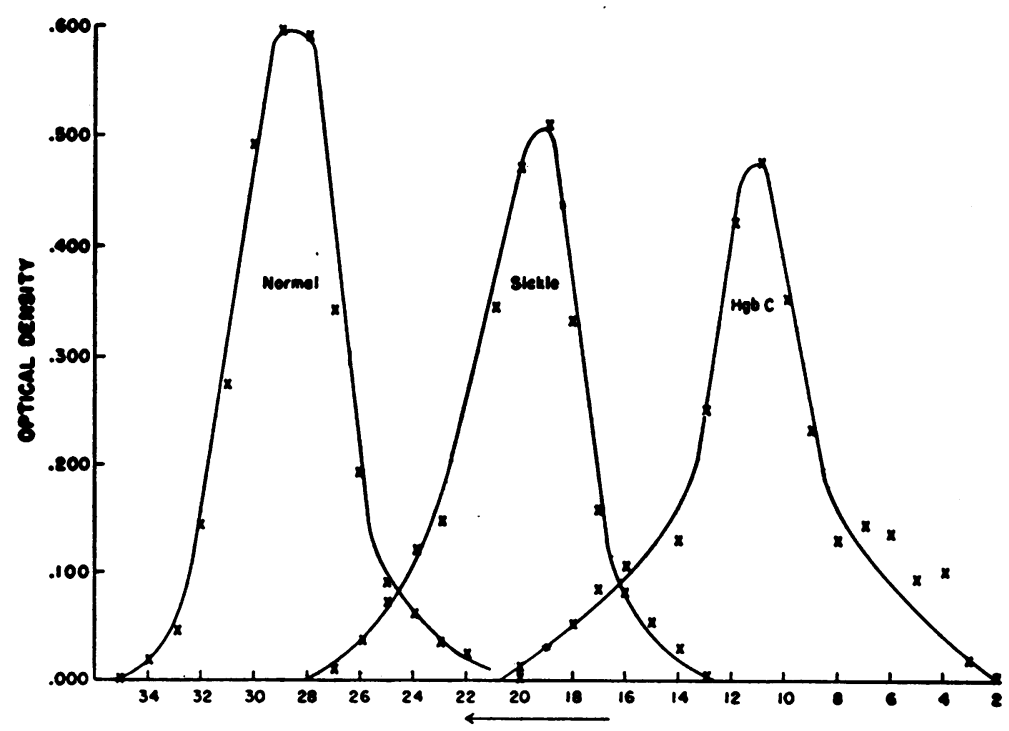

Fig. 4. Filter Paper Electrophoresis-Dye Elution Technique

Abscissa represents distance in centimeters from original site of placement of hemoglobin specimens (6). 


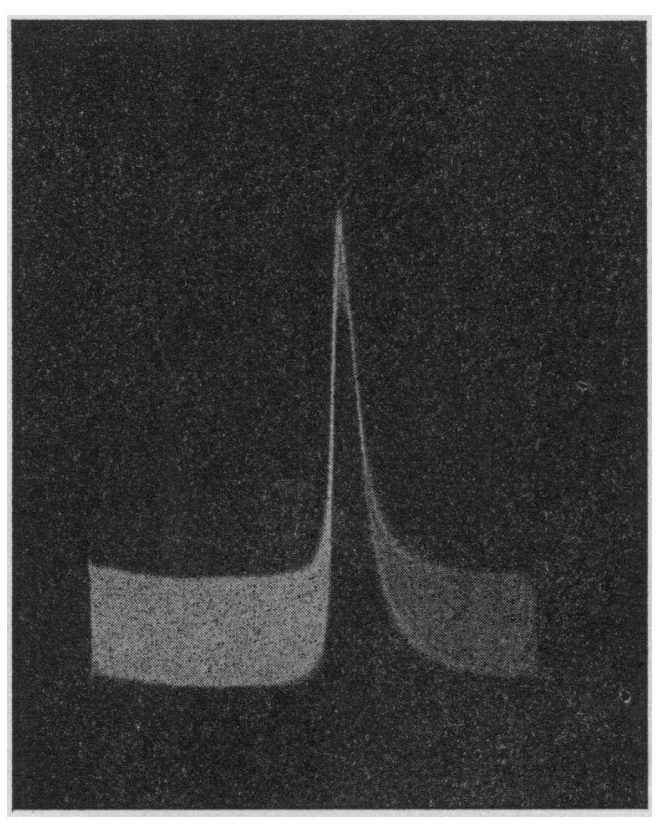

Fig. 5. Ascending Boundary of Hemoglobin C in Tiselius Apparatus

Conditions of analysis are given in text.

buffer, ionic strength $0.1, \mathrm{pH} 8.6$ was employed for these analyses; a preliminary 24-hour dialysis of the hemoglobin specimens against the veronal buffer was carried out. Values for mobility were the same for ascending and descending boundaries : $2.6 \times 10^{-5} \mathrm{~cm}^{2}$ volt $^{-1} \mathrm{sec}^{-1}$.

A photograph of the ascending boundary of one of these specimens is shown in Figure 5.

That there is a small amount of skewing present in this pattern is obvious. This may be the result of impurities in the hemoglobin specimen which was not crystallized, or it may result from an admixture with a small amount of another type of hemoglobin.

The electrophoretic properties of human hemoglobins including mobility studies have been summarized by Itano (7) who found the mobility of hemoglobin $\mathrm{C}$ in cacodylate buffer at $\mathrm{pH} 6.5$ to be $3.2 \times 10^{-5} \mathrm{~cm}^{2}{ }^{2}$ volt $^{-1} \mathrm{sec}^{-1}$.

The ultra-violet absorption spectrum of hemoglobin was determined with a Beckman DU spectrophotometer. The absorption spectrum of hemoglobin $C$ was found to be the same as that of normal hemoglobin.

Ultra-centrifugation studies of hemoglobin C yielded a sedimentation constant of $4.4 \times 10^{-13}$.
This is in good agreement with values of $4.4_{8} \times$ $10^{-13}$ obtained for normal hemoglobin by Pedersen (10).

Alkali denaturation of a sample of hemoglobin $C$ by the method of Singer, Chernoff, and Singer (11), showed 0.7 per cent alkali resistant hemoglobin. This is within the range of values obtained for normal hemoglobin.

The characteristic electrophoretic mobility, demonstrable by either moving boundary or filter paper electrophoresis, provides the only laboratory method for the identification of hemoglobin $\mathrm{C}$ at this time. Studies of the immunological properties and of the crystalline character of hemoglobin $\mathrm{C}$ are in progress.

\section{DISCUSSION}

Clinical and Hematological Manifestations $R e$ sulting from the Presence of Hemoglobin $C$

\section{The homozygous state with respect to the gene} for hemoglobin $C$

Since only one patient (M. B.), whose hemoglobin consists entirely of hemoglobin $\mathrm{C}$ was studied, no general conclusions can be drawn about the clinical syndrome. However, certain clinical and hematological features of the present case will be pointed out. This patient had virtually no symptoms except for three episodes of transient arthritis. She had splenomegaly for many years and the hemoglobin level remained at 10 to $12 \mathrm{Gm}$. per $100 \mathrm{ml}$. with mild reticulocytosis and erythroid hyperplasia of bone marrow. The stained smears showed nearly all the erythrocytes to be target cells. In contrast with many patients with sickle cell disease, this patient with "hemoglobin $\mathrm{C}$ disease" never had crises with anemia and had four uneventful pregnancies.

Although this patient had few manifestations of her hematologic disorder, her erythrocytes exhibited more marked abnormalities on stained blood smear (greater number of target cells and more marked poikilocytosis) than did the erythrocytes of any of the other patients in this report.

Kaplan, Zuelzer, and Neel (1) and Neel, Itano, and Lawrence (12) suggested that the homozygous state for the gene responsible for hemoglobin $\mathrm{C}$ might correspond to a previously recognized hematologic entity. Some of the reported cases of Mediterranean anemia occurring in Negroes may 
well have been individuals homozygous for hemoglobin C. In four such cases reported by Schwartz and Mason (13) large numbers of target cells were found, in addition to splenomegaly and decreased erythrocyte fragility. However, in two of their cases hemoglobin values were approximately 50 per cent, and in all, erythrocyte counts were disproportionately elevated with respect to the corresponding hemoglobin levels. It is, therefore, not possible to conclude from the available data whether any reported cases of Mediterranean anemia in the Negro were in reality examples of the homozygous state for hemoglobin $\mathrm{C}$. It seems preferable to classify M. B., the case reported here, as an example of "hemoglobin C disease," rather than to attempt to clarify the relationship to previously reported patients in whom electrophoretic studies of the hemoglobin were not done.

The combination of the genes for sickle cell hemoglobin and hemoglobin $C$

The outstanding clinical and hematological features of patients with the combination of the genes for sickle and $C$ hemoglobin are shown in Table I. This syndrome has been designated "sickle cellhemoglobin C disease" (7). Some clinical features which aid in distinguishing this disease state from sickle cell anemia have been pointed out by
Kaplan, Zuelzer, and Neel (1). The course is more benign, the anemia milder, and there is progressive splenic enlargement. It should be noted that the patients of the present study were somewhat older than those reported by Kaplan. In our patients, the anemia was milder and symptoms were fewer than in most patients with sickle cell anemia. However, one patient (M. S.) did not have a palpable spleen and another (M. D.) has a barely palpable spleen tip. In none of the patients has there been significant progression of the splenomegaly during the period of observation. Splenectomy, which was performed in one patient, did not correct the mild anemia.

An outstanding feature in the history of three of the patients was the occurrence of arthritis. In four patients (including the sister of M. S.) arthritis had been a major complaint. While polyarthritis occurs frequently in sickle cell anemia, the fact that it occurred in four of these patients with the combination of sickle and $\mathrm{C}$ hemoglobin as well as in patient M. B. who had only hemoglobin $\mathrm{C}$, is of interest. Obviously too few cases have been studied to draw any conclusions at this time.

Bone changes, which are frequently seen in classical sickle cell anemia were found in only two patients. One, patient E. H., had cortical defects in

TABLE I

Summary of clinical and hematological findings in five patients with the combination of the genes for sickle cell hemoglobin and hemoglobin $C$

\begin{tabular}{|c|c|c|c|c|c|c|c|c|}
\hline Patient & $\begin{array}{c}\text { Present } \\
\text { age }\end{array}$ & $\begin{array}{c}\text { Joint } \\
\text { symptoms }\end{array}$ & $\begin{array}{c}\text { Anemic } \\
\text { crises }\end{array}$ & $\begin{array}{l}\text { Spleno- } \\
\text { megaly* }\end{array}$ & $\begin{array}{l}\mathrm{X} \text {-ray } \\
\text { changes } \\
\text { in bones }\end{array}$ & $\begin{array}{c}\text { Usual } \\
\text { hemoglobin } \\
\text { levels } \\
\mathbf{G m . \%} \\
\end{array}$ & $\begin{array}{c}\text { Reticulo- } \\
\text { cytes } \\
\%\end{array}$ & $\begin{array}{c}\text { Target } \\
\text { cells } \\
\% \\
\end{array}$ \\
\hline M. S. & 15 & $\begin{array}{l}\text { frequent } \\
\text { arthritis }\end{array}$ & $t$ & none & none & $11-12$ & 3 & $\begin{array}{l}\operatorname{many} \\
(20-40 \%)\end{array}$ \\
\hline C. S. & 24 & $\begin{array}{l}\text { one severe } \\
\text { attack of } \\
\text { arthritis }\end{array}$ & $t$ & $5 \mathrm{~cm}$ & none & $10-13$ & 4 & $\operatorname{many}_{(30-40 \%)}$ \\
\hline C. W. & 27 & $\begin{array}{l}\text { frequent } \\
\text { arthralgias }\end{array}$ & yes & $3 \mathrm{~cm}$. & $\begin{array}{l}\text { ischemic } \\
\text { necrosis } \\
\text { left femoral } \\
\text { head }\end{array}$ & $10-12$ & $3-6$ & $\operatorname{many}_{(30-40 \%)}$ \\
\hline M. D. & 13 & $\begin{array}{l}\text { one attack } \\
\text { back pain }\end{array}$ & yes & $\begin{array}{l}\text { barely } \\
\text { palpable }\end{array}$ & none & $8-11$ & 4 & $\begin{array}{l}\text { occasional } \\
(4 \%)\end{array}$ \\
\hline E. H. & 13 & none & $\dagger$ & $4 \mathrm{~cm}$ & $\begin{array}{l}\text { cortical } \\
\text { defects } \\
\text { long bones }\end{array}$ & $10-12$ & $1-2$ & $\begin{array}{l}\text { frequent } \\
(10 \%)\end{array}$ \\
\hline
\end{tabular}

* Figure refers to centimeters palpated below left costal margin.

† No anemic crises ever documented. 
several long bones, which are of uncertain significance. The other patient (C. W.), however, has a severe deformity of the left femoral head, roentgengraphically indistinguishable from bony lesions associated with classical sickle cell anemia.

The hematological findings in these patients were similar to those previously reported (1). Nearly normal hemoglobin values, with a mild reticulocytosis, were found in all the patients. Two patients had crises accompanied by more severe anemia, but higher hemoglobin levels were quickly regained. Target cells were found on stained blood smears of all of the patients; in three of the patients, target cells constituted 50 to 60 per cent of the erythrocytes, but in two patients, target cells were as few as 10 and 4 per cent.

From the findings in the few recognized cases of the syndrome which accompanies the combination of sickle and hemoglobin C, it appears that this disorder has manifestations as variable as those of classical sickle cell anemia. At the present time it is not possible to arrive at the diagnosis of hemoglobin $\mathrm{C}$ in combination with sickle hemoglobin on clinical grounds alone. In adult patients, the clinical picture of sickle cell anemia may be extremely variable, and patients have been encountered who had some or all of the clinical and hematological features ascribed to the combination of sickle and $\mathrm{C}$ hemoglobin, but whose hemoglobin was entirely of the sickle variety as determined by filter paper electrophoresis.

\section{The combination of the genes for hemoglobin $C$ and normal hemoglobin}

Six subjects with hemoglobin $C$ trait were studied; they were completely symptom free and in none were any abnormalities found on physical examination. The hemoglobin values ranged from 11 to $12 \mathrm{Gm}$. per $100 \mathrm{ml}$. (within normal limits for the age groups to which the patients belonged). Reticulocytes were not significantly elevated, values ranging from 0.6 to 1.6 per cent. The occurrence of target cells in association with hemoglobin C trait has been noted previously (1); a few target cells were seen in the blood smears of all the individuals with hemoglobin $\mathrm{C}$ trait encountered in this study. In addition, mild degrees of hypochromia were noted in a few blood smears, but neither the number of target cells nor the degree of hypochromia was striking.

\section{SUM MARY}

The clinical and hematological findings in a patient whose hemoglobin was entirely of the hemoglobin $\mathrm{C}$ type have been described. The outstanding features were splenomegaly, striking numbers of target cells on stained blood smears, mild reticulocytosis, and a nearly normal hemoglobin level.

Five patients whose hemoglobin was a mixture of sickle and $\mathrm{C}$ hemoglobin were described. Although the clinical picture may be variable, most of these patients had splenomegaly with nearly normal hemoglobin values and a mild reticulocytosis. Two of the patients had crises with anemia and one patient had roentgenographic evidence of bone infarction.

Studies of the occurrence of hemoglobin $\mathrm{C}$ in various families confirm the theory proposed by Kaplan, Zuelzer, and Neel (1) that the presence of hemoglobin $\mathrm{C}$ is determined by a gene which is transmitted as a simple Mendelian dominant.

Studies of hemoglobin C including electrophoresis, ultra-centrifugation, ultra-violet absorption spectrum and alkali denaturation indicate that this abnormal hemoglobin can be identified only by electrophoresis at this time.

\section{ADDENDA}

Since this paper was submitted for publication, a patient homozygous for hemoglobin $\mathrm{C}$ has been described by T. Spaet (Pediatrics, In press).

Also, we have since encountered seven additional patients with the combination of the genes for sickle and $\mathrm{C}$ hemoglobin. Features of sickle cell hemoglobin $\mathrm{C}$ disease in these additional patients are similar to those reported.

\section{ACKNOWLEDGMENT}

The authors are grateful to Dr. James A. Wolff, of the Babies' Hospital, New York City, for permission to publish Cases 4 and 5; and to Grace Vanderhoff, B.S. for valuable technical assistance.

\section{REFERENCES}

1. Kaplan, E., Zuelzer, W. W., and Neel, J. V., A new inherited abnormality of hemoglobin and its in- 
teraction with sickle cell hemoglobin. Blood, 1951, 6, 1240.

2. Itano, H. A., and Neel, J. V., A new inherited abnormality of human hemoglobin. Proc. Nat. Acad. Sc., 1950, 36, 613.

3. Durrum, E. L., A microelectrophoretic and microionophoretic technique. J. Am. Chem. Soc., 1950, 72, 2943.

4. Kunkel, H. G., and Tiselius, A., Electrophoresis of proteins on filter paper. J..Gen. Physiol., 1951, 35, 89.

5. Spaet, T. H., Identification of abnormal hemoglobins by means of paper electrophoresis. J. Lab. \& Clin. Med., 1953, 41, 161.

6. Larson, D. L., and Ranney, H. M., Filter paper electrophoresis of human hemoglobin. J. Clin. Invest., 1953, 32, 1070.

7. Itano, H. A., Human hemoglobin. Science, 1953, 117, 89.

8. Shen, S. C., Castle, W. B., and Fleming, E. M., Experimental and clinical observations on increased mechanical fragility of erythrocytes. Science, 1944, n.s., $100,387$.

9. Drabkin, D. L., Spectrophotometric studies. XIV. The crystallographic and optical properties of the hemoglobin of man in comparison with those of other species. J. Biol. Chem., 1946, 164, 703.

10. Pedersen, $K$. O., The protein molecule in The Ultracentrifuge, by Svedberg, T., and Pedersen, K. O., Oxford, at the Clarendon Press, 1940, Table 48, opp. p. 406.

11. Singer, K., Chernoff, A. I., and Singer, L., Studies on abnormal hemoglobins. I. Their demonstration in sickle cell anemia and other hematologic disorders by means of alkali denaturation. Blood, 1951, 6, 413.

12. Neel, J. V., Itano, H. A., and Lawrence, J. S., Two cases of sickle cell disease presumably due to the combination of the genes for thalassemia and sickle cell hemoglobin. Blood, 1953, 8, 434.

13. Schwartz, S. O., and Mason, J., Mediterranean anemia in the Negro. A report of four cases and their families. Blood, 1949, 4, 706. 